\title{
PEMODELAN REGRESI NON LINEAR MENGGUNAKAN ALGORITMA GENETIKA UNTUK PREDIKSI KEBUTUHAN AIR PDAM KOTA MALANG
}

\author{
Vitara Nindya Putri Hasan ${ }^{1}$, Wayan Firdaus Mahmudy ${ }^{2}$, Mohammad Zoqi Sarwani ${ }^{3}$ \\ 1,2,2 Fakultas Ilmu Komputer/Informatika Universitas Brawijaya, Malang \\ Email: ${ }^{1}$ vitaranindyaph@gmail.com, ${ }^{2}$ wayanfm@ub.ac.id, ${ }^{3}$ zaki_swr@yahoo.com \\ (Naskah masuk: 18 Februari 2016, diterima untuk diterbitkan: 17 Maret 2016)
}

\begin{abstract}
Abstrak
Seiring dengan meningkatnya jumlah penduduk di Kota Malang maka meningkat pula kebutuhan konsumen air bersih dari PDAM. Perubahan pemakaian air tersebut jika tidak diolah dengan baik maka akan menyebabkan beberapa persoalan diantaranya apabila PDAM terlalu banyak mendistribusikan air bersih ke konsumen maka akan berakibat pemborosan air dan sebaliknya apabila distribusi air bersih PDAM kurang maka konsumen akan kekurangan air bersih. Oleh karena itu dibutuhkan suatu estimasi untuk memperkirakan dengan tepat seberapa besar volume air yang diperlukan di tahun-tahun berikutnya. Permasalahan tersebut dimodelkan dengan persamaan regresi non linear yang terdiri dari variabel bebas $(\mathrm{X})$ dan variabel terikat (Y). Algoritma Genetika digunakan untuk memilih variabel mana saja yang perlu dilibatkan dalam persamaan regresi. Proses reproduksi menggunakan one-point-crossover dan random mutation, untuk proses seleksinya menggunakan model elitism selection. Dari uji coba didapatkan parameter terbaik yaitu ukuran populasi sebanyak 225, generasi terbaik sebanyak 1750 generasi, kombinasi cr : mr adalah 0,6 : 0,4 dengan nilai fitness tertinggi yaitu 107.997. Hasil akhir berupa model regresi dengan melibatkan sesedikit mungkin variable bebas dan mean square error (MSE) terkecil..
\end{abstract}

Kata kunci: Regresi Non Linear, Algoritma Genetika, Prediksi, Pemakaian air PDAM

\begin{abstract}
Along with the increasing population in Malang the consumer water consumption from PDAM also increase. The change of water consumption if it is not treated properly, it will cause some problems when the PDAM has too many of water to distribute to consumers it will result in wastage of water and otherwise if the distribution of water less than normal, then the consumer will get a shortage of water. Therefore it is necessary to estimate for predict exactly how much the water volume needed in subsequent years. This problem will be modeled with non linear regression that consist of the independent variable $(X)$ and the dependent variable $(Y)$. Genetic Algorithm is applied to determine which variables are involved in the regression model. The reproduction process uses onepoint-crossover and random mutation, for the selection process uses a elitism selection models. The numerical experiment obtains the best population size is 225, the best generation as much as 1750 generation, combination of $\mathrm{cr}: \mathrm{mr}$ is $06: 0.4$ with the highest fitness value is 107.997. The final result is a regression model that involves less independent variabels with minimum mean square error (MSE).
\end{abstract}

Keywords: Non Linear Regression, Genetic Algorithm, Predict, Water Consumption

\section{PENDAHULUAN}

Semua makhluk hidup pasti memerlukan air. Air digunakan untuk berbagai macam keperluan mulai dari makan, minum, mandi, cuci, bekerja, dan berbagai kebutuhan lainnya. Air bersih adalah air yang telah memenuhi syarat kesehatan dan dapat digunakan untuk keperluan sehari-hari dalam melakukan berbagai aktivitas(Kesehatan, 1990). Badan yang menangani air bersih di Indonesia adalah Perusahaan Daerah Air Minum (PDAM). PDAM didirikan di setiap kota di Indonesia sebagai badan yang melayani kebutuhan masyarakat akan air bersih, salah satunya yang ada di kota Malang. Kota Malang adalah kota yang selalu mengalami peningkatan jumlah penduduk setiap tahunnya (Pemerintahan,
2015). Hal ini disebabkan oleh beberapa faktor diantaranya lokasi Kota Malang yang berada di daratan tinggi sehingga memiliki iklim sejuk, selain itu Malang memiliki fasilitas dan kualitas pendidikan yang memadai sehingga malang dijuluki sebagai kota pendikan (Indonesia, 2015). Faktor inilah yang mengakibatkan banyak yang memilih transmigrasi dan menetap tinggal di Malang. Seiring dengan meningkatnya jumlah penduduk di Kota Malang maka meningkat pula kebutuhan konsumen akan air bersih dari PDAM(Syaiful and Achmad, 2012).

Berdasarkan uraian ini maka PDAM harus meningkatkan kebutuhan air bersih setiap tahunnya guna memenuhi kebutuhan air bersih di Kota Malang. Tetapi dibutuhkan suatu estimasi untuk memperkirakan dengan tepat seberapa besar volume 
air PDAM Kota Malang yang diperlukan untuk melayani kebutuhan air para konsumen PDAM Kota Malang di tahun berikutnya agar tidak terjadi pemborosan atau kekurangan persediaan air untuk masyarakat.

Untuk mengatasi permasalahan ini diperlukan suatu analisis kebutuhan air konsumen PDAM dengan melakukan suatu pemodelan dengan metode regresi non linear menggunakan algoritma genetika. Regresi non linear adalah hubungan antara variable terikat (dependen, Y) dan variabel bebas (independent, X)(Yusnandar, 2004). Pada penelitian yang pernah dilakukan oleh Stonjavic, et al., (2013) yang bertujuan untuk menentukan model regresi linear (MLR) menggunakan algoritma genetika dalam sistem adaptif untuk bendungan Bocac di sungai Vrbas, Republic of Srpska. Hasil analisis menunjukan bahwa, dalam periode waktu dimana satu atau lebih sensor yang aktif menunjukan prediksi lebih baik daripada MLR asli yang mengasumsikan bahwa semua sensor selalu aktif. Berdasarkan penjelasan di atas bahwa model regresi yang dihasilkan melalui pendekatan algoritma genetika memberikan hasil yang lebih baik dibanding dengan model regresi. Sehingga penulis memilih model regresi non linear dengan menggunakan algoritma genetika.

\section{PENELITIAN TERKAIT}

Penelitian yang menggunakan metode regresi non linear pernah dilakukukan oleh Yusnandar (2014) untuk mengetahui sejauh mana aplikasi analisis regresi non linear model kuadratik terhadap produksi susu kambing PE selama 90 hari pertama laktasi. Dari hasil pengujian diperoleh persamaan regresi non linear model polynomial kuadratik pada analisis data produksi susu kambing PE selama 90 hari pertama laktasi dan tingkat maksimum produksi susu diketahui pada hari ke 20 setelah laktasi.

Pada kasus lain terdapat penelitian yang menggunakan pemodelan regresi linear dan algoritma genetika dalam konsumsi KWh listrik di Kota Batu yang dilakukan oleh Permatasari dan Mahmudy (2014). Pada koefisien yang dihasilkan oleh sistem menghasilkan nilai error yang lebih rendah dibandingkan dengan persamaan regresi.

Pada penelitian yang pernah dilakukan oleh Stonjavic, et al., (2013) yang bertujuan untuk menentukan model regresi linear (MLR) menggunakan algoritma genetika dalam sistem adaptif untuk bendungan Bocac di sungai Vrbas, Republic of Srpska. Hasil analisis menunjukan bahwa, dalam periode waktu dimana satu atau lebih sensor yang aktif menunjukan prediksi lebih baik daripada MLR asli yang mengasumsikan bahwa semua sensor selalu aktif.

\section{METODE}

\subsection{Data dan Variabel Penelitian}

Data yang digunakan pada penelitian ini berupa data time series bulanan pemakaian air PDAM mulai dari Januari 2008 sampai dengan Desember 2013. data ini diambil dari penelitian sebelumnya yang dilakukan oleh Irawan, et all (2015).

Model yang dibangun pada metode regresi non linear ini akan digunakan untuk menyelesaikan peramalan pemakaian air PDAM. Pada model non linear dalam parameternya bersifat kuadratik dan kubik dengan kurva yang dihasilkan membentuk garis lengkung (Yusnandar, 2004) selain itu, regresi non linear juga mempunyai banyak kurva yang bisa di bentuk(Sugiarto, 1992). Model regresi non linear terdapat variable terikat atau tidak bebas (Y) dan variable bebas (X). Nilai pemakaian air PDAM yang akan diprediksi dijadikan sebagai variable (Y) dan nilai pemakaian air PDAM pada $\mathrm{t}-1, \mathrm{t}-2, \mathrm{t}-3$ dan $\mathrm{t}-4$ dijadikan sebagai variable $(\mathrm{X})$, dimana $\mathrm{t}$ menunjukkan bulan.

Tabel 1. Variabel pada regresi non linear

\begin{tabular}{cl}
\hline Variable & \multicolumn{1}{c}{ Deskripsi } \\
\hline $\mathrm{t}$ & $\begin{array}{l}\text { Nilai yang akan diprediksi } \\
\text { Nilai pemakaian air PDAM pada bulan } \\
\text { sebelumnya }\end{array}$ \\
$\mathrm{t}-1$ & $\begin{array}{l}\text { Nilai pemakaian air PDAM pada } 2 \text { bulan } \\
\text { sebelumnya }\end{array}$ \\
$\mathrm{t}-2$ & $\begin{array}{l}\text { Nilai pemakaian air PDAM pada } 3 \text { bulan } \\
\text { sebelumnya }\end{array}$ \\
$\mathrm{t}-3$ & $\begin{array}{l}\text { Nilai pemakaian air PDAM pada } 4 \text { bulan } \\
\text { sebelumnya }\end{array}$ \\
$\mathrm{t}-4$ & $\begin{array}{l}\text { Nilai kuadrat pemakaian air PDAM pada } \\
\text { bulan sebelumnya }\end{array}$ \\
$(\mathrm{t}-1)^{2}$ & $\begin{array}{l}\text { Nilai kuadrat pemakaian air PDAM pada } 2 \\
\text { bulan sebelumnya } \\
(\mathrm{t}-2)^{2}\end{array}$ \\
$(\mathrm{t}-3)^{2}$ & $\begin{array}{l}\text { Nilai kuadrat pemakaian air PDAM pada } 3 \\
\text { bulan sebelumnya } \\
\text { Nilai kuadrat pemakaian air PDAM pada } 4 \\
\text { bulan sebelumnya }\end{array}$ \\
\hline $\mathrm{t}-4)^{2}$ & Pada
\end{tabular}

Pada persamaan (1) akan ditunjukkan persamaan regresi non linear yang digunukan untuk penelitian ini.

$t=a+b_{1}(t-1)+b_{2}(t-2)+b_{3}(t-3)+$
$b_{4}(t-4)+b_{5}(t-1)^{2}+b_{6}(t-2)^{2}+b_{7}(t-$
$3)^{2}+b_{8}(t-4)^{2}$

Hasil yang didapatkan dari hasil peramalan akan menggunakan metode regresi non linear akan dibandingkan dengan nilai sebenarnya untuk mengetahui seberapa besar perbedaannya. Metode yang digunakan untuk mengukurnya adalah Mean Square Error (MSE). Semakin besar nilai MSE maka semakin besar perbedaan hasil peramalan dengan data sebenarnya. Untuk menghitung MSE dapat menggunakan persamaan 2 berkut ini :

$M S E=\frac{1}{n} \sum_{i=1}^{n}\left(Y i-Y^{\prime} i\right)^{2}$

Keterangan :

$\mathrm{MSE}=$ merupakan Nilai error MSE

$\mathrm{n}=$ merupakan jumlah data yang diprediksi

$\mathrm{Yi}=$ merupakan nilai sebenarnya. 
$\mathrm{Y}^{\prime} \mathrm{I}=$ merupakan nilai hasil prediksi

$\mathrm{I}=$ indeks

\subsection{Struktur Algoritma Genetika}

Algoritma Genetika merupakan algoritma pencarian hasil terbaik yang berdasarkan pada seleksi alam dan genetika alam dengan melakukan proses reproduksi atau perkawinan. Pada Algoritma Genetika setiap individu dalam populasi dinamakan kromosom, setiap kromosom mewakili sebuah solusi untuk masalah yang akan dihadapi. Variabel solusi dikodekan ke dalam string yang memetakan barisan gen, yang akan menjadikan karakteristik dari sebuah solusi dari suatu permasalahan (Mahmudy, 2015).

Algoritma genetika yang terdapat pada penelitian ini digunakan untuk mengoptimasi persamaan regresi non linear untuk mendapatkan solusi yang terbaik. Algoritma genetika akan bekerja untuk menentukan jumlah parameter yang tepat pada persamaan regresi non linear.

\subsubsection{Representasi Kromosom}

Kromosom tersusun dari sejumlah gen yang menjadi calon solusi untuk masalah yang akan dihadapi Representasi kromosom terdiri dari berbagai bentuk yaitu representasi integer, biner, permutasi, dan real code(Mahmudy., 2015)

Representasi yang digunakan pada permasalahan dengan menggunakan pemodelan regresi non linear ini adalah representasi bilangan biner. Setiap variabel diwakilkan oleh angka (0) atau (1), jika (0) maka variabel tersebut tidak digunakan dan jika (1) maka variabel tersebut digunakan (Stonjavic et al., 2013)

Pada penelitian ini kromosom tersusun atas bilangan biner acak yang menyatakan orde periode data yang berpengaruh pada prediksi pemakaian air dengan model regresi non linear. Panjang kromosom dalam satu individu adalah dua kali jumlah periode data dimana $\mathrm{x} 1, \mathrm{x} 2, \mathrm{x} 3, \mathrm{x} 4$ adalah data aktual pemakaian air mulai dari (t-1) sampai dengan (t-4) dan $x 1^{2}, x 2^{2}, x 3^{2}, x 4^{2}$ adalah hasil perhitungan pangkat dari data aktual $\mathrm{x} 1, \mathrm{x} 2, \mathrm{x} 3, \mathrm{x} 4$.

Dalam menentukan model regresi non linear pada Tabel 2 indeks ke-1 hingga ke- 8 menyatakan periode data yang akan digunakan yakni periode pemakaian air pada saat (t-1) sampai dengan (t-4) dan hasil kuadratnya. Apabila nilai biner pada setiap gen berinilai 1 berarti data pada periode tersebut dipakai. dan apabila biner bernilai 0 maka data pemakaian air pada periode tersebut tidak digunakan(Stonjavic et al., 2013).

Tabel 2 Pembentukan Kromosom

\begin{tabular}{|c|c|c|c|c|c|c|c|}
\hline \multicolumn{7}{|c|}{ Kromosom } \\
\hline 1 & 2 & 3 & 4 & 5 & 6 & 7 & 8 \\
\hline $\mathrm{x} 2$ & $\mathrm{x} 2$ & $\mathrm{x} 2$ & $\mathrm{x} 4$ & $\mathrm{x} 1^{2}$ & $\mathrm{x} 2^{2}$ & $\mathrm{x} 3^{2}$ & $\mathrm{x} 4^{2}$ \\
\hline
\end{tabular}

\begin{tabular}{|l|l|l|l|l|l|l|l|}
\hline 0 & 0 & 1 & 1 & 0 & 0 & 0 & 0 \\
\hline
\end{tabular}

\subsubsection{Crossover}

Pada kasus ini metode crossover yang dipilih menggunakan metode one-point-crossover yaitu proses pemilihan dua induk secara acak dari populasi dan menghasilkan offspring (anak) dari kedua induk tersebut (Mahmudy et al., 2013b)., setelah itu menentukan titik sebagai cut point, gen yang berada di titik potong akan dipindah silang, dan hasilnya akan didapat anak (offspring) dari kombinasi kedua induk tersebut(Stonjavic et al., 2013). Pada penelitian ini populasi awal sebanyak 5 individu dengan crossover rate (cr) sebanyak 0,6 maka akan menghasilkan offspring $0,6 \times 5=3$. Berikut akan ditunjukan proses one cut point cross pada Gambar 1.

\begin{tabular}{|l|l|l|l|l|l|l|l|l|}
\hline P1 & 0 & 0 & 1 & 1 & 0 & 0 & 0 & 0 \\
\hline P3 & 0 & 1 & 1 & 1 & 1 & 0 & 0 & 0 \\
\hline C1 & 0 & 0 & 1 & 1 & 1 & 0 & 0 & 0 \\
\hline C2 & 0 & 1 & 1 & 1 & 0 & 0 & 0 & 0 \\
\hline
\end{tabular}

\begin{tabular}{|l|l|l|l|l|l|l|l|l|}
\hline P2 & 1 & 1 & 0 & 0 & 1 & 0 & 0 & 1 \\
\hline P5 & 1 & 0 & 0 & 0 & 0 & 0 & 0 & 1 \\
\hline C3 & 1 & 1 & 0 & 0 & 0 & 0 & 0 & 1 \\
\hline
\end{tabular}

Gambar 1. Crossover

\subsubsection{Mutasi}

Proses mutasi yang digunakan adalah random mutation yaitu sebuah proses acak dimana memilih salah satu gen didalam kromosom yang ditentukan untuk kemudian dirubah nilainya dari 0 menjadi 1 dan sebaliknya(Mahmudy et al., 2013b) (Stonjavic et al., 2013). Dengan mutation rate sebesar 0.4 maka banyaknya offspring yang dihasilkan adalah 0.4 × $5=$ 2. Proses mutasi akan ditunjukan pada Gambar 2. 


\begin{tabular}{|c|c|c|c|c|c|c|c|c|}
\hline P4 & 0 & 0 & 0 & 0 & 1 & 1 & 0 & 0 \\
\hline $\mathrm{C4}$ & 0 & 0 & 0 & 1 & 1 & 1 & 0 & 0 \\
\hline P5 & 1 & 0 & 0 & 0 & 0 & 0 & 0 & 1 \\
\hline C5 & 1 & 0 & 0 & 1 & $\overline{0}$ & 0 & 0 & 1 \\
\hline
\end{tabular}

Gambar 2. Mutasi

\subsubsection{Fungsi Fitness}

Fungsi fitness digunakan untuk mengukur kebaikan solusi yang dibawa oleh suatu individu. Individu terbaik dengan nilai fitness yang tinggi cenderung menghasilkan solusi yang terbaik. Fungsi fitness yang digunakan untuk masalah pemodelan regresei non linear dalam kebutuhan air ditunjukkan pada Persamaan (2.25).

Dimana :

$$
\text { fitness }=\frac{c}{\text { error }}+\frac{1}{1+(\alpha \times n)}
$$

$$
\begin{array}{ll}
\mathrm{c} & =\text { constanta } \\
\mathrm{n} & =\text { Jumlah kromosom bernilai 1 } \\
\text { error } & =\text { Nilai MSE yang dihasilkan } \\
\alpha & =0,1
\end{array}
$$

\subsubsection{Seleksi}

Proses selanjutnya adalah seleksi yaitu mengeliminasi kromosom yang memiliki fitness rendah. Tujuanya adalah untuk mempertahankan individu yang mempunyai nilai fitness tinggi agar dapat bertahan hidup pada generasi selanjutnya. Pada proses seleksi ini dilakukan dengan mengumpulkan semua kromosom parent dan offspring dalam satu penampungan(Stonjavic et al., 2013).

Pada penelitian ini metode yang digunakan adalah elitsm selection yaitu memilih individu berdasarkan popSize terbaik dengan mengurutkan individu-individu dari nilai fitness tertinggi sampai terendah (Mahmudy et al., 2013a) Individu dengan nilai fitness yang lebih besar dibanding dengan individu yang lain merupakan kromosom terbaik dalam populasi yang mampu bertahan hidup pada generasi selanjutnya. Jumlah Individu terbaik yang bertahan hidup diambil sesuai dengan popSize yang telah ditentukan sebelumnya. Metode elitism selection akan menjamin menghasilkan individu yang terbaik dan akan selalu lolos dalam seleksi(Mahmudy, 2013b).

Hasil akhir berupa hasil seleksi individuindividu terbaik sejumlah populasi awal untuk dilanjutkan ke generasi selanjutnya. Hasil seleksi individu terbaik ditampilkan pada Gambar 3

\begin{tabular}{|c|c|l|l|}
\hline $\mathbf{P}$ & $\mathbf{P}(\mathbf{t}-1)$ & & \\
\hline P1 & P3 & {$[\mathrm{x} 2],[\mathrm{x} 3],[\mathrm{x} 4],\left[\mathrm{x} 1^{2}\right]$} & 1.023961717 \\
\hline P2 & C3 & {$[\mathrm{x} 1],[\mathrm{x} 2],\left[\mathrm{x} 4{ }^{2}\right]$} & 0.970993768 \\
\hline P3 & P1 & {$[\mathrm{x} 3],[\mathrm{x} 4]$} & 0.930121905 \\
\hline P4 & C5 & {$[\mathrm{x} 1],[\mathrm{x} 4],\left[\mathrm{x} 4{ }^{2}\right]$} & 0.919619409 \\
\hline P5 & P2 & {$[\mathrm{x} 1],[\mathrm{x} 2],\left[\mathrm{x} 1^{2}\right],\left[\mathrm{x} 4{ }^{2}\right]$} & 0.910642509 \\
\hline
\end{tabular}

Gambar 3. Seleksi

Setelah dilakukan proses seleksi, maka dilanjutkan dengan memilih kromosom terbaik yang dapat ditentukan berdasarkan nilai fitness terbesar. Pada Gambar 3, kromosom yang memiliki fitness terbesar adalah parent ke-1

\section{HASIL DAN PEMBAHASAN}

Pada penelitian ini, akan dilakukan beberapa uji coba untuk mendapatkan solusi terbaik. Uji coba dilakukan dengan mencari parameter algoritma genetika yang terbaik dan menguji jumlah periode yang tepat.

\subsection{Pengujian Jumlah Periode.}

Pengujian periode data ini dilakukan untuk mengetahui banyaknya periode pemakaian air (dalam bulan) yang optimal berdasarkan dari hasil rata-rata fitness terbaik. Data periode pemakaian air yang digunakan dimulai dari 4 bulan kebelakang sampai 20 bulan kebelakang. Dengan menggunakan ukuran populasi yaitu 60 populasi, jumlah generasi yaitu 10 generasi, dan kombinasi cr dan mr yaitu 0.6:0.4. Untuk data yang di uji menggunakan data pemakaian air PDAM dari tahun 2008 sampai 2013. Setiap periode yang diuji akan dilakukan 10 kali percobaan. Hasil percobaan banyaknya perode ditunjukan pada Tabel 2 .

Tabel.2 Pengujian Banyaknya Periode

\begin{tabular}{ccc}
\hline No & Banyak Periode & Rata-rata nilai fitness \\
\hline 1 & 4 & 89.346 \\
2 & 6 & 89.545 \\
3 & 8 & 97.082 \\
4 & 10 & 97.739 \\
5 & 12 & 90.082 \\
6 & 14 & 58.161 \\
7 & 16 & 49.053 \\
8 & 18 & 34.299 \\
9 & 20 & 27.800 \\
\hline
\end{tabular}

Pada Tabel 2 didapatkan jumlah perode yang terbaik adalah terdapat pada jumlah perode 10 dan dengan nilai rata-rata fitness 97.729.

\begin{tabular}{|l|l|l|l|}
\hline Asal & Asal & Model & Fitness \\
\hline
\end{tabular}




\subsection{Pengujian Ukuran Populasi}

Pengujian ukuran populasi ini bertujuan untuk mengetahui ukuran populasi yang optimal dengan mengacu dari hasil rata-rata fitness terbaik pada permasalahan prediksi kebutuhan air. Data yang digunakan dalam pengujian ukuran populasi ini sebanyak 340 data pemakaian air PDAM untuk prediksi 4 bulan kebelakang mulai tahun 2008 sampai 2013. Jumlah generasi yang dipakai adalah 2000 dengan banyak populasi kelipatan 25, mulai dari 25 popSize sampai 250 popSize. Nilai crossover rate yang digunakan adalah 0,6 dan mutation rate yang digunakan adalah 0,4. Setiap ukuran populasi yang diuji akan dilakukan 10 kali percobaan. Untuk hasil percobaan ukuran populasi ditunjukkan pada Tabel 3.

Tabel 3 Skenario Pengujian Ukuran Populasi (popSize)

\begin{tabular}{ccc}
\hline $\begin{array}{c}\text { Banyak } \\
\text { PopSize }\end{array}$ & $\begin{array}{c}\text { Rata-rata nilai } \\
\text { fitness }\end{array}$ & $\begin{array}{c}\text { rata-rata waktu } \\
\text { (detik) }\end{array}$ \\
\hline 25 & 90.250 & 40.2 \\
50 & 93.041 & 75.8 \\
75 & 98.705 & 86.8 \\
100 & 101.991 & 93 \\
125 & 98.939 & 101.4 \\
150 & 102.665 & 119.2 \\
175 & 107.265 & 143.1 \\
200 & 107.934 & 162.9 \\
225 & 111.808 & 177.6 \\
250 & 111.959 & 198.7 \\
\hline
\end{tabular}

Dari hasil uji coba populasi didapatkan jumlah populasi terbaik sebanyak 225 dengan rata-rata nilai fitness yaitu 111.808. Pada percobaan dengan ukuran populasi sebanyak 125 mengalami penurunan nilai rata-rata fitness meski tidak signifikan, tetapi percobaan selanjutnya menunjukan nilai rata-rata fitness mengalami kenaikan dikarenakan semakin banyak populasi yang dihasilkan maka peluang untuk menghasilkan generasi dengan solusi terbaik semakin besar(Mahmudy, 2013b).

\subsection{Pengujian Banyaknya Generasi.}

Pengujian banyaknya generasi ini dilakukan untuk mengetahui ukuran generasi yang optimal berdasarkan dari hasil rata-rata fitness terbaik. Banyak generasi yang akan dilakukan dengan kelipatan 250 mulai dari 250 generasi sampai 2000 generasi. Menggunakan hasil uji coba ukuran populasi terbaik pada pengujian sebelumnya yaitu 225 populasi, nilai crossover rate dan mutation rate yang digunakan yaitu 0.6:0.4. Untuk data yang digunakan dalam pengujian ukuran populasi ini sebanyak 340 data pemakaian kebetuhan air PDAM untuk prediksi 4 bulan kebelakang mulai tahun 2008 sampai 2013. Setiap ukuran generasi akan dilakukan 10 percobaan. Hasil percobaan banyaknya generasi ditunjukan pada Tabel 4.

Tabel 4 Pengujian Banyaknya Generasi

\begin{tabular}{|c|c|c|}
\hline No & Jumlah Generasi & Rata-rata nilai fitness \\
\hline 1 & 250 & 88.228 \\
\hline 2 & 500 & 94.943 \\
\hline 3 & 750 & 97.222 \\
\hline 4 & 1000 & 98.745 \\
\hline 5 & 1250 & 100.339 \\
\hline 6 & 1500 & 105.693 \\
\hline 7 & 1750 & 109.482 \\
\hline 8 & 2000 & 109.840 \\
\hline iad & $\begin{array}{l}\text { hasil uji co } \\
\text { lan ukuran gener } \\
\text { gan rata-rata nilai } \\
\text { sebesar } 250 \text { deng } \\
\text { generasi terenda } \\
\text { belum mela } \\
\text { Permatasari and } \mathrm{M}\end{array}$ & $\begin{array}{l}\text { generasi didapat } \\
\text { si terbaik adalah sebe } \\
\text { fitness } 109.482 \text {. Pada } \\
\text { n rata-rata fitness } 88 . \\
\text { dikarenakan algorit } \\
\text { xukan proses sec } \\
\text { ahmudy, 2014). }\end{array}$ \\
\hline
\end{tabular}

\subsection{Pengujian Kombinasi Crossover Rate dan Mutation Rate}

Pengujian kombinasi crossover rate (cr) dan mutation rate $(\mathrm{mr})$ ini dilakukan untuk mengetahui kombinasi cr dan mr yang optimal berdasarkan hasil rata-rata fitness terbaik. Pada percobaan ini kombinasi $\mathrm{cr}$ dan $\mathrm{mr}$ berjumlah 1 . Dengan menggunakan ukuran populasi terbaik yang telah diuji sebelumnya yaitu 225 populasi dan jumlah generasi terbaik sesuai dengan percobaan sebelumnya yaitu 1750 generasi. Data yang digunakan dalam pengujian kombinasi cr dan $\mathrm{mr}$ ini sebanyak 340 data pemakaian air PDAM untuk prediksi 10 bulan kebelakang mulai tahun 2008 sampai 2013. Setiap kombinasi cr dan mr yang diuji akan dilakukan 10 kali percobaan. Hasil percobaan kombinasi cr dan mr ditunjukan pada Tabel 4.

Tabel 5 Hasil Uji Coba Kombinasi Crossover Rate (cr) dan Mutation Rate (mr) 
64 Jurnal Teknologi Informasi dan Ilmu Komputer (JTIIK), Vol. 3, No. 1, Maret 2016, hlm. 59-65

\begin{tabular}{cccc}
\hline & & & \\
\cline { 1 - 2 } $\mathbf{c r}$ & $\mathbf{M r}$ & \\
\hline 1 & 0 & 105.867 \\
0.9 & 0.1 & 107.013 \\
0.8 & 0.2 & 103.302 \\
0.7 & 0.3 & 107.290 \\
0.6 & 0.4 & 110.252 \\
0.5 & 0.5 & 102.613 \\
0.4 & 0.6 & 109.939 \\
0.3 & 0.7 & 103.365 \\
0.2 & 0.8 & 106.688 \\
0.1 & 0.9 & 107.748 \\
0 & 1 & 106.505 \\
\hline & &
\end{tabular}

Pada percobaan dalam membentuk regresi non linear dengan algoritma genetika solusi terbaik yang diberikan untuk algoritma genetika yaitu pada ukuran popSize sebesar 225, generasi terbaik sebanyak 1750 generasi, kombinasi nilai crossover rate dan mutation rate terbaik yaitu $0.6: 0.4$.

Persamaan dari model regresi non linear yang terbentuk dengan algoritma genetika ini akan dibandingkan dengan persamaan regresi non linear yang juga dapat melakukan prediksi di bulan selanjutnya.

Sampel data yang diambil untuk testing perbandingan menggunakan pemakaian selama 25 bulan. Perbandingan antara data aktual (yang sebenarnya) dengan hasil prediksi model regresi non linera dengan melibatkan semua variabel serta model regresi non linear yang dibentuk dengan algoritma genetika dapat dilihat pada Tabel 6 .

\begin{tabular}{|c|c|c|c|c|}
\hline \multirow{2}{*}{$\begin{array}{l}\text { Data } \\
\text { Aktual }\end{array}$} & \multirow{2}{*}{$\begin{array}{l}\text { Prediksi } \\
\text { dengan } \\
\text { Regresi }\end{array}$} & \multirow{2}{*}{$\begin{array}{c}\text { Prediksi } \\
\text { dengan Algen }\end{array}$} & Error Regresi & Error GA \\
\hline & & & \multicolumn{2}{|c|}{$\left(Y_{i}-Y^{\prime}{ }_{i}\right)^{2}$} \\
\hline 1606972 & 1613939.056 & 1628993.928 & 48539870.46 & 484965316 \\
\hline 1558064 & 1559682.551 & 1543730.829 & 2619708.318 & 205439792 \\
\hline 1773087 & 1765555.022 & 1804400.275 & 56730696.51 & 980521185.3 \\
\hline 1658690 & 1652439.504 & 1699838.989 & 39068694.84 & 1693239282 \\
\hline 1680750 & 1683713.16 & 1730606.593 & 8780319.056 & 2485679905 \\
\hline 1765834 & 1771281.536 & 1728341.631 & 29675644.1 & 1405677740 \\
\hline 1799518 & 1798813.23 & 1825805.532 & 496700.1629 & 691034331.8 \\
\hline 1763284 & 1757549.303 & 1762365.357 & 32886748.63 & 843905.5054 \\
\hline 1837567 & 1852024.338 & 1773967.301 & 209014625 & 4044921768 \\
\hline 1698905 & 1696006.899 & 1797882.307 & 8398987.44 & 9796507213 \\
\hline 1772154 & 1735972.362 & 1717332.663 & 1309110953 & 3005378952 \\
\hline 1732172 & 1759987.911 & 1773294.318 & 773724894.5 & 1691045051 \\
\hline 1694870 & 1717093.846 & 1717175.906 & 493899332.5 & 497553459.4 \\
\hline 1751939 & 1725442.68 & 1720383.558 & 702054995.6 & 995745931.4 \\
\hline 1807659 & 1793975.072 & 1717269.51 & 187249884.2 & 8170259929 \\
\hline 1752567 & 1817925.311 & 1763774.637 & 4271708789 & 125611116.3 \\
\hline 1773785 & 1806373.278 & 1732648.582 & 1061995843 & 1692204889 \\
\hline 1901589 & 1840326.386 & 1765789.678 & 3753107883 & 18441455811 \\
\hline 1858807 & 1834457.563 & 1822500.007 & 592895084.4 & 1318197719 \\
\hline 1825106 & 1807663.543 & 1779285.395 & 304239312.9 & 2099527821 \\
\hline 1869328 & 1879971.244 & 1854179.068 & 113278643.3 & 229490148.3 \\
\hline 1820043 & 1854904.558 & 1859285.51 & 1215328239 & 1539974627 \\
\hline 1780592 & 1786086.47 & 1789475.243 & 30189201.26 & 78912002.28 \\
\hline 1861409 & 1864996.847 & 1809906.88 & 12872647.42 & 2652468368 \\
\hline 1913115 & 1881624.33 & 1858277.714 & 991662309.1 & 3007127947 \\
\hline & & rror & 16249530007 & 67333784210 \\
\hline & & $F$ & 5098.945774 & 10379.50166 \\
\hline & & ness & 196.6745269 & 96.89929465 \\
\hline
\end{tabular}

Pada Tabel 6 didapatkan nilai error MSE untuk model regresi non linear yang terbentuk dengan algoritma genetika sebesar 10379.50166. Sedangkan nilai error untuk regresi non linear sebesar 5098.945774 yang tanpa melibatkan algoritma genetika, meskipun nilai error MSE yang dihasilkan dibentuk dengan algoritma genetika lebih besar namun variabel yang terlibat lebih sedikit. Hal ini dipengaruhi oleh jumlah alfa yang digunakan pada proses perhitungan fitness. Apabila nilai alfa yang digunakan adalah 0 maka variabel yang dihasilkan oleh model regresi akan terlibat semua dan jika nilai alfa diperbesar maka jumlah variabel yang dihasilkan oleh model regresi akan semakin sedikit. Secara prinsip lebih sedikit variabel yang terlibat maka lebih baik(Stonjavic et al., 2013). Oleh karena itu model regresi non linear yang dibentuk dengan algoritma
Tabel 6. Detail Error Regresi dan Error Algoritma Genetika 
genetika lebih baik dibandingkan dengan regresi non linear.

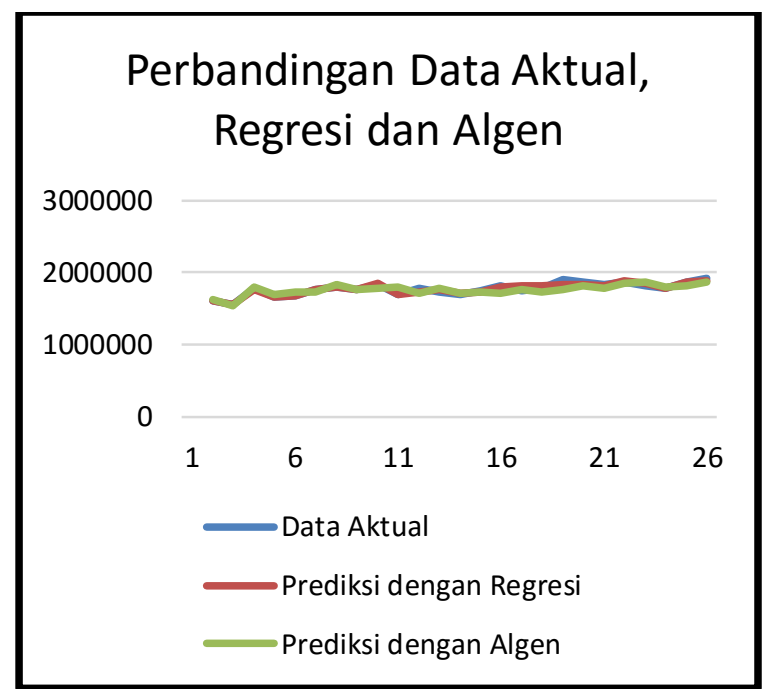

Gambar 4. Perbandingan Data Aktual,Regresi dan Hasil Prediksi

\section{PENUTUP}

Dari hasil uji coba yang dilakukan pada kasus prediksi pemakaian air PDAM menggunakan algoritma genetika untuk pemodelan regresi non linear mampu memberikan hasil yang baik. Parameter yang terdapat pada algoritma genetika memeiliki pengaruh yang besar terhadap hasil yang didapatkan. Uji coba untuk mendapatkan jumlah populasi yang terbaik adalah pada saat jumlah populasinya sebesar 225 dengna nilai rata-rata fitnessnya adalah 111,808. sedangkan jumlah generasi terbaik adalah sebanyak 1750 generasi dengan nilai fitness 109,842. Dan kombinasi terbaik untuk nilai crossover rate dan mutation rate adalah 0,6 dan 0,4 dimana nilai fitness yang didapatkan sebesar 110,252. Akan tetapi pada penelitian ini nilai error yang didapatkan algoritma genetika dengan menggunakan parameter terbaik lebih besar dibandingkan nilai error yang didapatkan regresi non linear. Hal ini dikarenakan model regresi non linear yang dibentuk dengan algoritma genetika menggunakan variable yang lebih sedikit dibandingkan dengan regresi non linear.

Pada penelitan selanjutnya hibridisasi algoritma genetika bisa dilakukan untuk menghasilkan model regeresi yang lebih baik.

\section{DAFTAR PUSTAKA}

INDONESIA, P., 2015. 7 Alasan Ini Akan Memperkuat Kamu Untuk Kuliah di Kota Malang. [Online] Available at: www.pedidikanindonesia.com [Accessed 21 Januari 2016].

IRAWAN, DEWI, C. \& CHOLISSODIN, I., 2015. Implementasi Metode Jaringan Syaraf Tiruan Backpropagation Pada Peramalan
Kebutuhan Air PDAM Kota Malang. DORO : Repository Jurnal Mahasiswa PTIIK Universitas Brawijaya, Volume 6, p. 11.

KESEHATAN, D. 1990. Peraturan Menteri Kesehatan RI No 416/Menkes/Per/IX/1990 Tentang Syarat-syarat dan Pengawasan Kualitas Air. Jakarta: Departermen Kesehatan RI.

MAHMUDY, W. F. 2015. Dasar-Dasar Algoritma Evolusi, Program Teknologi Informasi dan Ilmu Komputer, Universitas Brawijaya, Malang.

MAHMUDY, W. F., MARIAN, R. M. \& LUONG, L. H. S. 2013a. Modeling and optimization of part type selection and loading problems in flexible manufacturing system using real coded genetic algorithms. International Journal of Electrical, Computer, Electronics and Communication Engineering, 7, 251-260.

MAHMUDY, W. F., MARIAN, R. M. \& LUONG, L. H. S. 2013b. Real coded genetic algorithms for solving flexible job-shop scheduling problem - Part I: modeling. Advanced Materials Research, 701, 359363.

PEMERINTAHAN, B. 2015. LKPJ Tahun Anggaran 2014.

PERMATASARI, A. I. \& MAHMUDY, W. F. 2014. Pemodelan Regresi Linear dalam Konsumsi Kwh Listrik di Kota Batu Menggunakan Algoritma Genetika. DORO: Repository Jurnal Mahasiswa PTIIK Universitas Brawijaya, 5.

STONJAVIC, B., MILIVOJEVIC, M. \& IVANOVIC, M. 2013. Adaptive System For Dam Behavior Modeling Based In Linear Regression And Genetic Algorithms. IEEE, 65, 182-190.

SYAIFUL \& ACHMAD 2012. Segudang Prestasi dan Layanan PDAM.

YUSNANDAR 2004. Aplikasi Analisis Regresi Non Linear Model Kuadratik Terhadap Produksi Susu Kambing Peranakan Etawah (PE) Selama 90 Hari Pertama Laktasi. Informatika Pertanian, 13, 736-743. 